\title{
Bone memory: the necrogeography of the Armenian Genocide in Dayr al-Zur, Syria
}

\section{Elyse Semerdjian Whitman College}

semerdve@whitman.edu

\begin{abstract}
This article discusses how Armenians have collected, displayed and exchanged the bones of their murdered ancestors in formal and informal ceremonies of remembrance in Dayr al-Zur, Syria - the final destination for hundreds of thousands of Armenians during the deportations of 1915. These pilgrimages - replete with overlapping secular and nationalist motifs - are a modern variant of historical pilgrimage practices; yet these bones are more than relics. Bone rituals, displays and vernacular memorials are enacted in spaces of memory that lie outside of official state memorials, making unmarked sites of atrocity more legible. Vernacular memorial practices are of particular interest as we consider new archives for the history of the Armenian Genocide. The rehabilitation of this historical site into public consciousness is particularly urgent, since the Armenian Genocide Memorial Museum and Martyr's Church at the centre of the pilgrimage site were both destroyed by ISIS (Islamic State in Syria) in 2014.
\end{abstract}

Key words: Armenian Genocide, pilgrimage, memory, memorials, Syria, ISIS

'I wanted to bond with our people's grief, to make it part of my body and consciousness ... I wanted to go from Lebanon to Dayr al-Zur - that immense graveyard of our martyrs.' Armenian poet Hamasdegh wrote these words in an essay titled 'With a Skull' after his own pilgrimage in the Syrian desert in 1929. The essay described 'ribs ripped apart from spinal columns, knee caps and skulls', scattered fragments of bone comingling and protruding from the soil. In the context of the essay, the skull is not an inanimate object, but a companion who actually speaks to the poet and essayist as they journey to the 'immense graveyard of our martyrs' in the desert. He writes: 'We became travel companions the skull and I. Intimate friends sharing stories of green fields and desert days, me and the skull.' In the final lines, Hamasdegh imagines the awakening of bones resurrected by Haik, the mythical founder of the Armenian nation, whose trumpet will call the bones to form ranks of soldiers who will rise to reclaim their ancestral homeland. In the imagined narrative of the essay, the scattered bones of ancestors are both witnesses to genocide and historical agents in the making of a future Armenia within the affective landscape of Dayr al-Zur. 
This article tells the story of displaced bones - the remains of Armenian Genocide victims that are enmeshed in memorial rituals and pilgrimages within the necrogeography of Dayr al-Zur, Syria. In what follows I illustrate and analyse the ways in which Armenians have collected, displayed and exchanged the bones of their murdered ancestors, in formal and informal ceremonies of remembrance. Replete with overlapping secular and nationalist motifs, these pilgrimages are a modern variant of historical pilgrimage practices; yet these bones are more than relics. Bone rituals and displays are enacted in spaces of memory that lie outside of official state memorials, making unmarked sites of atrocity more legible. Vernacular memorial practices are of particular interest as we consider new archives for the study of the Armenian Genocide. Through an interdisciplinary reading of memoirs, poems and oral interviews this article is a preliminary attempt to document the experience of Armenian pilgrimage within the deathscape of the Euphrates and Khabur river basins that converge on the city of Dayr al-Zur, a place that until recently was held by the Islamic militant group ISIS. The article seeks to rehabilitate the memory of a historical site into public consciousness, since the Armenian Genocide Memorial Museum and Martyrs' Church at the centre of the pilgrimage were both destroyed by an explosion in 2014. The multiple layers of bone and trauma contained within the geography of Dayr al-Zur pose a challenge to this reconstruction, but also offer an opportunity to consider the shared trauma among both Armenians and local Dayri Arabs in this troubled border zone over the last hundred years.

The affective quality of the bones instigates a shift in perspective from human to material agency, prompting us to consider how bones cause us to act, rather than what we do with bones. ${ }^{2}$ Bones move us to tears and make us feel things that we wouldn't feel without contact with them. Joost Fontein has found, in the case of tortured and murdered bodies in Zimbabwe, that the process of unearthing and reburial of remains has given families the opportunity to narrativise the past in honour of the dead and make demands on the living. ${ }^{3}$ Scholars within the materialist turn have urged us to contest the clear boundary between body and object. They have argued that the body should not be viewed as a perfectly contained vessel, and instead consider the complex exchanges between bodies, objects and environment. Thinking with these theorists, what do bones do to those who make pilgrimages (including the local Arab residents who live among them) in Dayr al-Zur? How do Armenians describe the compulsion to collect, display and keep the bones of their murdered ancestors? How are these forms of collecting, exchange and display ethically understood by those who engage in these practices?

\section{If these bones could speak: the affective deathscape of Dayr al-Zur}

'If these stones, fields, and desert sands could speak, what stories would they tell?'4

Two decades ago, I searched for recollections of Armenian journeys to the Syrian desert described in Hamasdegh's poem. In Aleppo, I located an out-of-print book by a local Armenian doctor, Robert Jebejian, who had systematically documented his own scientific reconstruction of the Armenian deportation route from Aleppo to Dayr al-Zur and Ra's al-Ayn. Jebejian recorded the major deportation 


\section{Elyse Semerdjian}

and mass-murder sites in Syria with the help of photographer Hagop Krikorian. The result of this research was the self-published volume Routes and Centers of Annihilation of Armenian Deportees of 1915 Within the Boundaries of Syria (Aleppo, 1994), a book that served as the guide for my own self-directed first-time pilgrimage to the desert in 2000. Jebejian's work was a crucial resource prior to the emergence of online first-person pilgrimage testimonies, but has important documentary value now that the site has become inaccessible due to war. ${ }^{6}$

While Krikorian took his photographs decades after the Genocide, he followed a tradition of displaying Armenian remains in various states of decomposition in World War I photography. The production and dissemination of such images were primarily evidentiary, aimed at confirming the facts of genocide through the 'objective' lens of the camera. ${ }^{7}$ Among these early photographs is Harutyun Hovakimyan's expedition to Dayr al-Zur in 1938. As he holds the skull of an Armenian Genocide victim in his hand, his colleague gestures to it with his left hand while holding bones in the right (Figure 1). The image not only emphasises the sheer volume of bones discovered in eastern Syria after the war but compels the viewer to witness the war crime along with the excavation team. Yet, photography has conversely been used in the service of Turkish state denialism in which Armenian mass graves are Turkified. Necropolitical power is projected across the border into Syria to counteract public memory and remembrance practices of Armenian deaths in these spaces. ${ }^{8}$ Such denial renders the bones (not to mention Armenian lives) subject to disposal, as the state affirms Turkish biopower over each newly discovered mass grave. The Turkish ambassador to the United States, Nabi Şensoy, quipped, 'Bones you can find anywhere in Turkey. There have been a lot of tragedies in those lands.' Hence, even

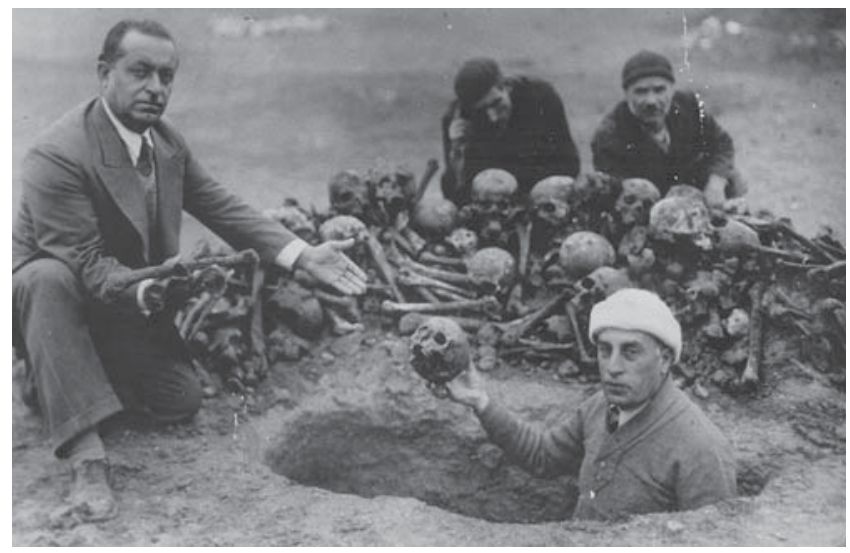

Figure 1 A 1938 expedition of Armenians led by Harutyun Hovakimyan, holding a skull, in Dayr al-Zur. Published with permission from the Armenian Genocide Museum Institute. All rights reserved; permission to use the figure must be obtained from the copyright holder. 
when the bones of murdered ancestors are grasped in the hands of pilgrim witnesses, genocide recognition remains elusive. But while bones may be insufficient evidence of a war crime for Turkish officials, for Armenian pilgrims they have the inverse effect. For Armenians, bones from mass-grave sites possess a powerful agency to bear witness to genocide.

Much of the human remains in the deserts of Dayr al-Zur continue to be picked through, dug up, collected and kept by people seeking to symbolically unearth the truth of 1915 that lies beneath the sand. By digging up bones with Armenian pilgrims, Arab residents perform what I will term empathic excavations, which symbolically recognise the atrocities committed whilst simultaneously reinforcing collective memory of the history embedded in the very topology of the landscape. While the bone collectors are sometimes Arabs, the bone keepers are almost always Armenian. Scenes of Armenians collecting bones frequently appear in historical photographs and films about the sites, such that unearthing bones in and around Dayr al-Zur has been a consistent and even clichéd aspect of the iconography of Armenian memory practices for some time. Armenian pilgrimages over the last hundred years are only occasionally preserved in writing.

Peter Balakian preserved his account in an essay titled 'Bones', published in the New York Times Magazine in 2008. ${ }^{10}$ In the essay, the Pulitzer Prize-winning poet and Armenian Genocide scholar offered a first-person account of his travels to Dayr al-Zur and Margada. Balakian's career has been spent documenting the history of the Armenian Genocide and Dayr al-Zur in documentaries, news reports, non-fiction writing and poetry. ${ }^{11}$ In the light of all that has happened in Syria since 2011, his writings are now more than non-fiction essay writing; they are important historical documentation of Armenian pilgrimage rituals in eastern Syria, rituals interrupted by the current war. Just two years before the civil war broke out in 2011, Balakian visited all three pilgrimage sites in Dayr al-Zur, Margada and Shaddadi for the filming of a 60 Minutes segment on the Armenian Genocide. ${ }^{12}$ The voiceover remarks: 'Dayr al-Zur is to Armenians what Auschwitz is to the Jews.' While it may hold similar necrogeographic significance, in many ways Dayr al-Zur is not Auschwitz. There is a public memory of the Holocaust, and Auschwitz is now a formal memorial, maintained by the state of Poland as a national museum since 1947. As for Dayr al-Zur, only Armenians and local Arabs visit these sites, and most of the actual sites of mass atrocity have been left to the elements to decay. The only formal memorial was created by the Armenian Apostolic Church of Syria under the jurisdiction of the Armenian Catholicosate in Antelias, Lebanon, not by the government of Syria, nor by the government of Armenia. The absence of care outside of the church memorial set Dayr al-Zur apart from other memorials; affectively, the empty, neglected landscape urged the witness to fill the space with memory.

Before there was an Auschwitz, Peter Balakian's great uncle, priest Grigoris Balakian, described Dayr al-Zur as 'the center of the desert and the largest cemetery of the exiled Armenians. ${ }^{13}$ If we are to think of Dayr al-Zur as the largest cemetery of Armenian Genocide victims, how should we understand the relationship between the structure of the site and the events, past and present, that have shaped it? How have history and recent events in the region structured the geography and 
public memory of the space? In order to think through the affective landscape in and around Dayr al-Zur, we need to first explore the material, political and human elements that constitute its making.

Straddling the border of north-eastern Syria and southern Turkey, the Euphrates and Khabur river basins have witnessed a century of violence. At the time of the genocide, north-east Syria comprised the Arabic-speaking boundaries of the Ottoman empire. Many are familiar with the arbitrary boundaries of the modern Middle East designed by the Sykes-Picot agreement (1916). Less known, perhaps, is that the Treaty of Sèvres (1920) negotiated between the Allies and the Ottoman empire recognised an independent Armenian homeland in what is today eastern Turkey as reparations for the pain and suffering of genocide. ${ }^{14}$ For three years after World War I, the boundaries of modern Armenia were joined with historic Armenian homelands located in the Ottoman eastern provinces. However, parts of the Armenian republic, along with other lands occupied by the Allied powers and Greece, fell to the forces of Mustafa Atatürk and by 1923 the modern Turkish republic was formed with the political boundaries that we recognise today. Yet, both states - Turkey and Syria - have unstable borders that threaten to betray the state as diverse groups of people hold mixed allegiances. Arabs, Turks, Armenians and Kurds share some cross-border experiences and affinities - hinting to the limits of the modern state's capacity to contain national identity.

Armenians have been ensnared by the ambivalence of the Syrian state, which at times instrumentalised the Armenian Genocide to put pressure on Turkey during escalations of tension in the late 1990s, only later to suppress expression when relations warmed between the two nations - a phenomenon that has garnered little to no scholarly attention. While Hafez al-Asad nearly went to war with Turkey over water shortages caused by the construction of dams, Bashar al-Asad's economic opening warmed relations with Turkish businesses, prompting suppression of discussion about the Armenian Genocide within Syria. ${ }^{15}$ After 2005, new books about the Armenian Genocide were removed from the shelves, processions were ordered to be more muted, drumming and chants were stopped and outrage was to be replaced with quiet, solemn grief and politely contained within church walls so as to not offend Syria's neighbour to the north. ${ }^{16}$

The cliffs surrounding the Euphrates and Khabur basins were natural deportation routes during the genocide, the landscape itself was weaponised. Dayr al-Zur is a deathscape, a place associated with death and imbued with meaning by people who carry with them the memory of catastrophic loss, and remember it through ritual. ${ }^{17}$ Grigoris vardapet describes the desert as a liminal space where the norms of humanity no longer applied as Armenian deportees were tortured, raided, abducted and enslaved by a combination of tribal groups, gendarmes and Ottoman irregular forces. Grigoris vardapet describes how an unnatural environment was manufactured by the killings as witnesses encountered bodies and body parts in various states of decomposition: 'We saw caravans of women, completely naked because the Yeneze bandits who greeted the caravans had taken even their undergarments. We came across corpses as naked as the day they were born and with eyes gouged out; all their limbs had been cut off for sport and their bodies were swollen; their 
entrails were spilled out; during the daytime, the vultures would descend on these corpses and feast, while it was the wild animals' turn at night.' ${ }^{18}$

In 1916, a year after the initial killings of Armenian deportees, reports of typhus epidemics within the eastern provinces of the Ottoman empire produced a macabre paradox. Armenian bodies had been haphazardly flung from bridges and cliffs into ravines, valleys and rivers, where they decomposed, inviting disease back into the communities that had murdered them. Waterways choked with corpses contaminated the water and made it undrinkable. With the outbreak of cholera, the landscape itself was becoming a vector for disease that threatened non-targeted populations. Raymond Kévorkian has shown that the cycle of contagion prompted a shift in Ottoman policy. The land was to be cleared of all remnants of Armenians, who were to be killed outside major towns and buried in mass graves in order to protect Muslim populations threatened with disease.

Armenian corpses, now regenerated by contagion, prompted the authorities to advise new methods of disposal - burial and burning - to protect the Muslim population from the threat of contagion. ${ }^{19}$ Grigoris vardapet laments that the burials he witnessed were not ritualistic but were instead performed by Muslim labourers who were brought out to cleanse the land of Armenian bodies. The priest's memoirs describe how multiple pits, trenches and natural caves were used to dispose of bodies and control the contagion. The landscape was scarred by mounds that marked the sites where mass burials had been performed months before:

The land stretching before us from Islahiye seemed like a battlefield for the plain was covered with innumerable large and small mounds of earth. These were the graves of Armenians who had been buried fifty or a hundred at a time, and though winter had passed, the mounds of earth had kept their convex shape - and alas, some were veritable hills ... When we were seized with the thought that these were human hills, filled with Armenians ... our despair and demoralization reached such a level that we contemplated suicide. ${ }^{20}$

Reflecting on the history and memory contained within the landscape of Dayr al-Zur only highlights how the bone remnants serve as vernacular markers to remind pilgrims of what the landscape looked like during the genocide. In this sense, pilgrims are witnessing the present landscape while imagining that of the past described to them by survivors. We will turn now to the sites of pilgrimage, where what I call bone memory is created within a landscape through empathic gestures by local Arabs, mourning rituals and the collection of material bone fragments by pilgrims and local residents.

\section{A pilgrimage in three parts: Dayr al-Zur, Margada and Shaddadi}

Before the outbreak of the Syrian uprising-turned-war in 2011, Armenian pilgrimages to the desert typically included visits to three memorial stations, only two of which - Dayr al-Zur and Margada - were formally marked with memorials. The trip would usually begin with the Holy Martyrs church and Armenian Genocide 
Memorial at Dayr al-Zur. Sometimes included in the Dayr al-Zur trip was the al-Busayra mass-grave site. The second stop was typically Margada, where the St Haroutioun chapel and monument are located. ${ }^{21}$ The third stop, at the caves of Shaddadi, was ill-prepared for tourists and therefore less frequently made. The first two sites are more formal memorials that include human bones encased in glass ossuaries commissioned by the Armenian Apostolic Church rather than by the state, while the Shaddadi station is informal to the extent that pilgrims must find local residents to assist in locating the site. The order of the stops follows the path of Armenian victims who were forcibly marched on foot down the Euphrates river basin, gathered in Dayr al-Zur and then marched along the Khabur river and killed in stages along the way. The final site on the journey, Shaddadi, is one of the final resting sites where Armenians were gathered to be taken to caves in the desert and burned alive. ${ }^{22}$ Using a combination of oral interviews and auto-ethnography, I will reconstruct these three stations of pilgrimage in and around Dayr al-Zur to document a ritual that has since halted and may not start up again for some time (Figure 2).

The first station of the pilgrimage - the since destroyed Armenian Genocide Memorial church in Dayr al-Zur - belonged to the Armenian Apostolic Church of Syria. Armenian pilgrimages to Dayr al-Zur were largely performed by Syrian and Lebanese Armenians and always began with a very long church service in the morning of 24 April, followed by some patriotic songs and optional roaming in the desert afterwards. As a result of annual pilgrimages conducted under the auspices of the Armenian prelate in Aleppo, a more formal museum and monument was planned for Dayr al-Zur. Ground was broken in the mid-1980s and a memorial designed by architect Sarkis Balmanoukian was completed by $1990 .^{23}$ The Armenian Martyrs church occupied the first floor of the church, while the bottom floor was the location of a memorial made of beautifully gold-toned marble (Figures 3, 4 and 5).

One respondent described her affective response to the Armenian Genocide Memorial in these words:

I have extreme difficulty crying. My body tenses up and prohibits me from releasing tears. Something about the design of the church. There is a safety to the expression of sadness in that church. I felt that I could cry there. There was an intimacy to it. A warmth to it in the way the church was designed. It wasn't one of those old churches where you feel intimidated by the presence of a God. Rather, I felt embraced and humbled by the memory of what that church contains. You know how the architecture of the church can awake different emotions and can make you feel small or grand, it made me feel connected and it made me think about all that this land had been witnessing. If we want to be able to recognise the pain that we are going through today, people who live on this land, we have to remember the pain that the land withstood before. ${ }^{24}$

At the centre of the monument was a marble pillar lined with six gold-coloured traditional Armenian crosses (khatchars) that reached up through the lower floor to the main floor of the building. At the foot of the pillar were the remains of Armenian Genocide victims, their bones carefully laid out in a glass ossuary - the closest thing to a proper burial that these human remains have received since 1915 . The remains 


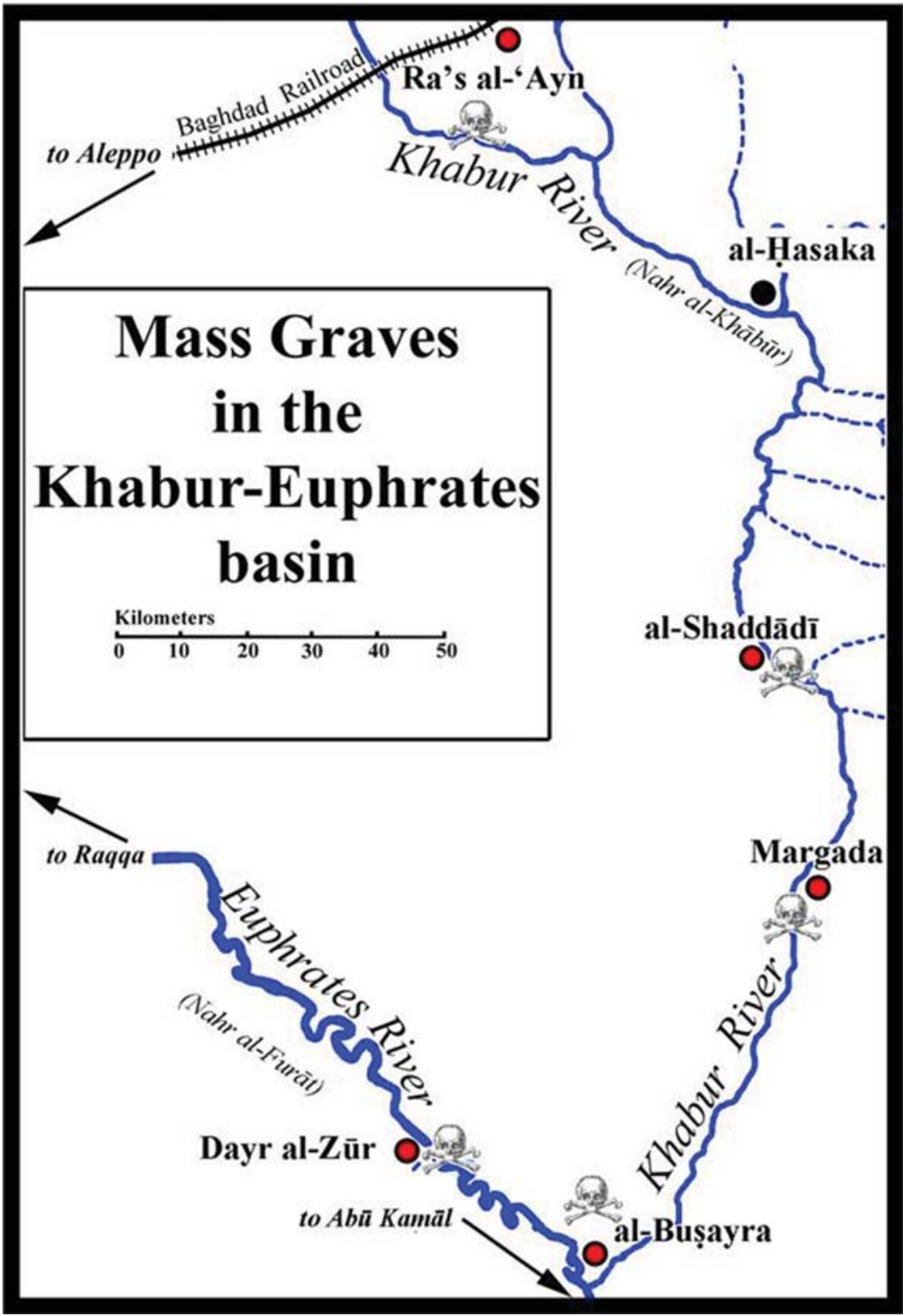

Figure 2 Mass graves in the Khabur-Euphrates basin are some of the well-known sites visited by Armenian pilgrims. Map drawn by Geoff Schad. All rights reserved; permission to use the figure must be obtained from the copyright holder. 


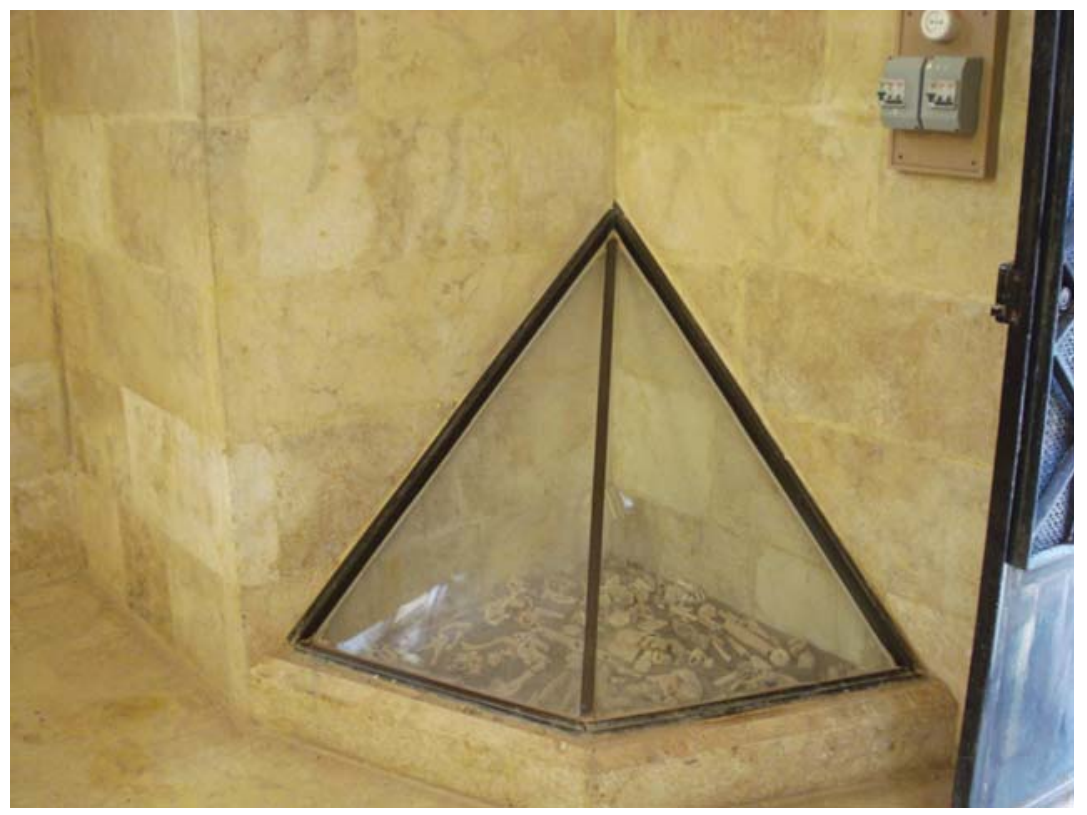

Figure 3 The small ossuary at the St Haroutiun chapel at Margada, Syria. Photo by author. All rights reserved; permission to use the figure must be obtained from the copyright holder.

on display in the memorial were collected by Harutyun Hovakimyan, featured in Figure 1 holding a skull in his hand. During that 1938 exhibition, his team gathered bones from the pit featured in the photograph. They also collected the remains of Armenian children from under the Dayr al-Zur bridge, and other bones at the Shaddadi and Margada sites. Hovakimyan packed the bones into three boxes which were later interred in the Dayr al-Zur Genocide Memorial ossuary in 1990.

For the visitor meditating on the structure of the ossuary, earth and bone dislocated from their original contexts served as metonyms for both the nation and the body. The viewer was immediately thrown into dual mourning when viewing both material objects - marble pillar and ossuary - within a single monument. The ossuary held carefully arranged individual fractured bone that, while fragmented, cohered into a whole to be mourned - the nation destroyed. ${ }^{25}$ Small vials of soil encircled the pillar, each labelled with the various points of origin - Ani, Aintab, Marash, Van - places from which Armenian victims were deported to meet their ultimate death in the desert. Both the earth and the human remains were hermetically sealed in glass, yet are suggestive of the ritual of sprinkling the dead with soil taken from the homeland to which the exiled bones originally belonged. In this sense, the memorial evoked religious and nationalist metonyms simultaneously to emphasise the twin pillars of Armenian identity. 


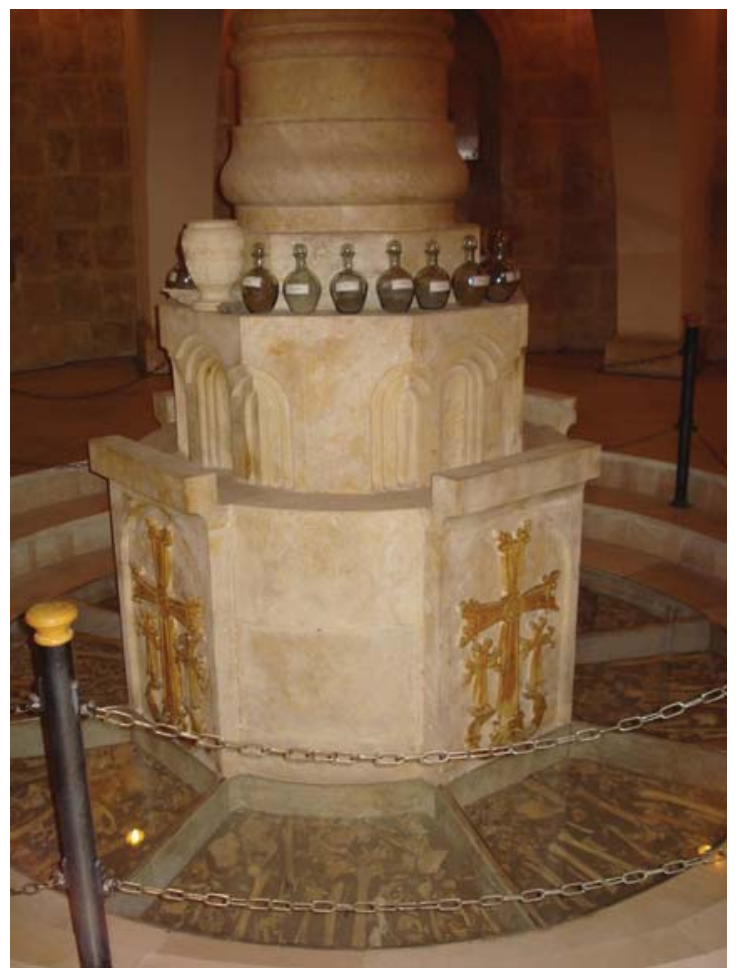

Figure 4 The Armenian Genocide Memorial inside the Armenian Martyrs' church in Dayr al-Zur. The monument contains crosses (khatchars) that traditionally adorn Armenian gravestones, soil from the points of origin of Armenian deportees, and bones encased in an ossuary at the foot of the memorial. Photo by author. All rights reserved; permission to use the figure must be obtained from the copyright holder.

The second stop, Margada - about 70km north of Dayr al-Zur - is the site of a mass grave where an estimated $80,000-100,000$ souls perished on the march between Margada and Shaddadi. ${ }^{26}$ One could probably pass Margada, situated in a vast swath of unforgiving desert, without even noticing it. There is little settlement there, which fits the pattern of many mass-grave sites outside Dayr al-Zur. From the road, one sees a large mound of earth. What does not appear until a closer glance is that the earth is packed with human bones. In 1999, the same decade as the Dayr al-Zur memorial complex and church were completed, St Haroutioun chapel was built by the Armenian Apostolic Church to offer official recognition for those who perished at Margada. The red sandstone-walled structure contains a tiny one-chamber chapel that also serves as a monument, with a small triangular ossuary for the human bones that are displayed there. 


\section{Elyse Semerdjian}

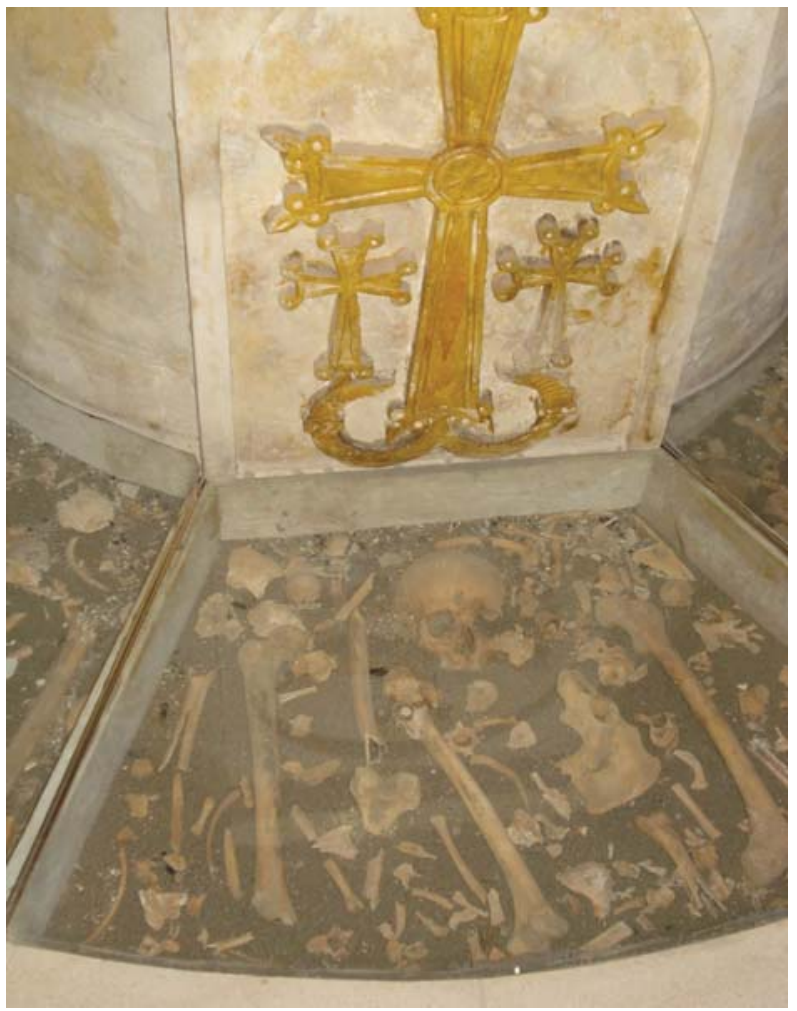

Figure 5 The Armenian Genocide Museum monument within the Armenian Martyrs' church at Dayr al-Zur. Photo by author. All rights reserved; permission to use the figure must be obtained from the copyright holder.

Not far from Margada, on the road to Hassaka, is the third pilgrimage station, Shaddadi, a small town of newer construction that sprung up around the oil industry. Hugging the Khabur river is the original village of Shaddadi. Armenian deportees from Aleppo were held for six months in Dayr al-Zur, where hundreds died daily of hunger and disease. In June 1916, approximately 200,000 Armenians were deported north of Dayr al-Zur to the killing fields where they were executed by Chechen irregulars. ${ }^{27}$ On 15 July 1916, 18,000 Armenian women and children were marched into the desert, crossing the Zur bridge and arriving Shaddadi a few days later; there the survivors of the march were gathered on a mound next to the river. ${ }^{28}$ The villagers remember how girls were gathered on the mound of Tel Shaddadi one night, and the district chief, knowing they were to be killed the next day, sheltered some of the girls in the homes of residents to save them. Those who remained were marched into the desert and burned alive at the cave where Armenian pilgrims now descend to bear witness at the site. ${ }^{29}$ 


\section{Bone memory}

In more ideal environments, memorials inject a 'politics of public affect' into public space. ${ }^{30}$ Yet, within the politically contested zone of the Euphrates river basin, affect is generated within informal memorial sites by Armenian pilgrims and local Dayris who served as guides, interpreters, diggers and collectors of bone. These vernacular pilgrimages were immaterial micro-performances permitted by the authoritarian state. Before the war, these small political encroachments were certainly visible to the Syrian state; pilgrims repeatedly note how the secret police (mukhabarat) surrounded them on their visits, following them from site to site. But it is clear that the pilgrimages were deemed non-threatening by the state, because they were allowed to continue even as relations warmed between Syria and Turkey by 2005. One respondent compared his interactions with the Syrian secret police to 'the keystone cops'. A Syrian intelligence agent approached not to intimidate him during his visit to alBusayra, but to help guide his tour, telling him where more Armenian bones could be located. ${ }^{31}$ Other respondents noted that the secret police were present but did not disturb the group, indicating that the trips appeared to be non-threatening to the authoritarian state. This is why, perhaps, focusing on Dayr al-Zur versus a more formally state-recognised space of Armenian Genocide memorial, such as the Tsitsernakaberd in Yerevan, where the 'the entire country turns out for a funeral that the victims never had', makes for a more unique study of what I call bone memory - the informal ritual displays and interactions of Armenians with bone that work to produce communal memory in the mostly unmarked necrogeography of Dayr al-Zur. ${ }^{32}$ Like the liminal region within which they are situated, these Armenian memorial displays are vernacular, everyday forms of political encroachment ${ }^{33}$ that take place within an unmarked and contested terrain that lies largely outside the grasp of the state.

An important aspect of Armenian vernacular pilgrimage ritual is the digging up of bones from the earth. Widely practised by Armenians of the region, the ritual became more public when diasporan Armenian Peter Balakian documented the ritual when he took 60 Minutes to the sites described above. At one point the journalist remarked, 'The most ghoulish thing about the place is that the evidence is everywhere.' The evidence is in the soil and in the memories of the local residents, of whom Balakian says, 'Look at this, we got kids who know this area picking up bones by the dozens.' A few years earlier Balakian had described the act of bone collecting when he wrote: 'I put my hand in the dirt, grazing the ground, and came up with hard white pieces. He continues, “'Our ancestors are here," I muttered. Then I began, without thinking, picking up handfuls of dirt, sifting out the bones and stuffing them in my pockets. I felt the porous, chalky, dirt-saturated, hard, intangible stuff in my hands. A piece of hip socket, part of a skull. Nine decades later. ${ }^{34}$ Filling his pockets with bones and dirt, the author describes placing them inside a Ziploc bag and stuffing them into his carry-on luggage to take back home.

Many pilgrims have followed the footsteps of their ancestors and Balakian in the Syrian desert. Armenian Genocide historian and activist Khatchig Mouradian 
organised a diverse group of four intellectuals for a trip to Dayr al-Zur in September 2009, a year after Balakian's essay was published. This group made a oneday visit to the church and museum in Dayr al-Zur and the al-Busayra mass-grave site. I interviewed Khatchig and several members of the group because of its unusual composition. Unlike other tours, this one was not organised by the Church or by specific members of the Armenian community. Instead, it was a trip of Khatchig's design, two Armenian and two non-Armenian witnesses - one Arab LebaneseSyrian and the other Turkish. While there were opportunities to go to Dayr al-Zur on 24 April from Lebanon, Khatchig noted, 'I didn't just want to go there and weep and cry with other Armenians, I wanted to go with a Turk.'35 He invited a friend, journalist Amberin Zaman, to go, and when she accepted he said, 'I got my Turk!' Amberin describes Khatchig's decision to take a Turk on his first visit to the site as 'Khatchig's dream': however, Khatchig frames it differently, noting that 'I always had an issue with getting large groups of people to go to a site in the absence of any larger broader acknowledgement. It's important to make it part of a broader experience and that is why David was there.' Here he referred to progressive Armenian activist and radio host David Barsamian, who joined the group. For Khatchig, going to Dayr al-Zur was a purely political act, to the extent that he objects to referring to the trip as a pilgrimage.

In the course of the visit, a priest helped to guide their tour and struck up a conversation in Turkish with Amberin. The fourth traveller in the group, Rania al-Masri, was shocked that the Armenian priest slipped into Turkish so easily. She asked him, 'How could you speak Turkish here? You could speak Turkish anywhere. How can you speak it here?' She continued, 'He said, I speak Turkish to her because I speak her language so that she can really understand because people empathise when you speak to them in the mother tongue. The strength of this man. I just wanted to kiss his hands. It still takes my breath away. ${ }^{36}$ According to Amberin, she had asked the priest in Turkish, 'Have any Turks ever come here before?' The priest replied, 'No, you are the first.' This, for her, was a profoundly disturbing realisation. Others observed that she was visibly shaken by the realisation that not a single Turk had come before her.

During the course of the pilgrimage, Amberin recalled school children at the alBusayra site pressing bones into her hands and performing empathic excavations so as to witness to the crime along with the pilgrims. Bones are not incidental objects of fascination. They evoke both affect and transcendence going back to early traditions of relics in which Armenians participated historically, most profoundly the collection of St Gregory the Illuminator's hand at the Holy Mother See at Etchmiadzin, Armenia. Karmen MacKendrick's analysis of relics and memory invites us to consider the ways that fragments of bone symbolise our own inevitable fragmentation, a vivid reminder of our eventual decomposition. They also serve as important objects invested with mnemonic powers, as sanctified relics are 'where memory is understood as the reproduction of a clear narrative line, as if the relics were illustrations in a history textbook. ${ }^{37}$ The invocation of history at these sites through both formal and vernacular markers necessarily leads us to consider the collective memory embedded in the space as one where identity is constituted. Rather than locate 
history as a temporally remote event, Jean-Luc Nancy considers it to be emotionally contained within the community:

History - if we can remove this word from its metaphysical, and therefore historical, determination - does not belong primarily to time, nor to succession, nor to causality, but to community, or to being-in-common. This is so because community itself is something historical. Which means that it is not substance, nor a subject; it is not a common being, which could be the goal or culmination of a progressive process. It is rather a being-in-common that only happens or that is happening, an event, more than a 'being. ${ }^{38}$

Nancy's definition of history is conveyed by Armenian pilgrims who enacted the collective memory of the Armenian Genocide alongside Armenians and Arab descendants of Armenians during their pilgrimages.One Armenian pilgrim, UKbased actress and writer Nouritza Matossian, made an impromptu trip to Dayr al-Zur with a group of Armenians from Damascus who sought to share the experience with her in 2001. A few years later, she made another trip, this time alone, to spend more time at the site and interact more with the local residents. ${ }^{39}$ She recounts from her original trip that the car grew more quiet as they approached Dayr al-Zur. When they stopped at a river to refresh themselves, they realised with a shock that it was a river that had once been filled with Armenian bodies during the Genocide. At the second station, St Haroutioun chapel at Margada, locals shared memories with Matossian, narrating how the atrocity had made an impact on the affective landscape within which they lived. During the trip, she learned popular myths from the locals; for example, one woman informed her 'there is a plant, if you break the leaf, blood comes out', while another told her, 'local people never eat fish from this river'. Locals shared collective memories of how the landscape looked during the Genocide, which in turn imprinted them into the consciousness of Armenian pilgrims. ${ }^{40}$

Matossian admitted that, like many other pilgrims, she collected bones in Dayr al-Zur and took them with her when she left. When I asked her what she did with the bones and whether she kept them she answered, 'No, I buried the bones in Cyprus at the Armenian church.' She found it unethical to take the bones as a souvenir of her pilgrimage. In her view, the bones needed to be laid to rest in sanctified soil, 'they should be buried and treated with respect'. This is where Matossian's photograph of her souvenir box, purchased from the Dayr al-Zur Armenian Genocide Memorial gift shop, enters the story (Figure 6). The box contained several symbolic objects, all of them religious: a vial of soil to be scattered over the dead; two candles to be lit in prayer for the deceased; and a vial of incense to be burned at the 'grave' site. The ceremony box featured a wooden cross, inscribed in Armenian with the words 'Dayr al-Zur, April 24, 1915', which resembles a miniature grave marker for the pilgrim to either use on site or carry home as a souvenir (Figure 6). I asked Matossian to interpret the symbolism of the two ears of wheat included among the items. She suggested that the wheat represented the bread typically received along with communion wine. While the bread represents the breaking of bread with Christ and his disciples at the Last Supper, the bread is also figuratively transformed into the body 


\section{Elyse Semerdjian}

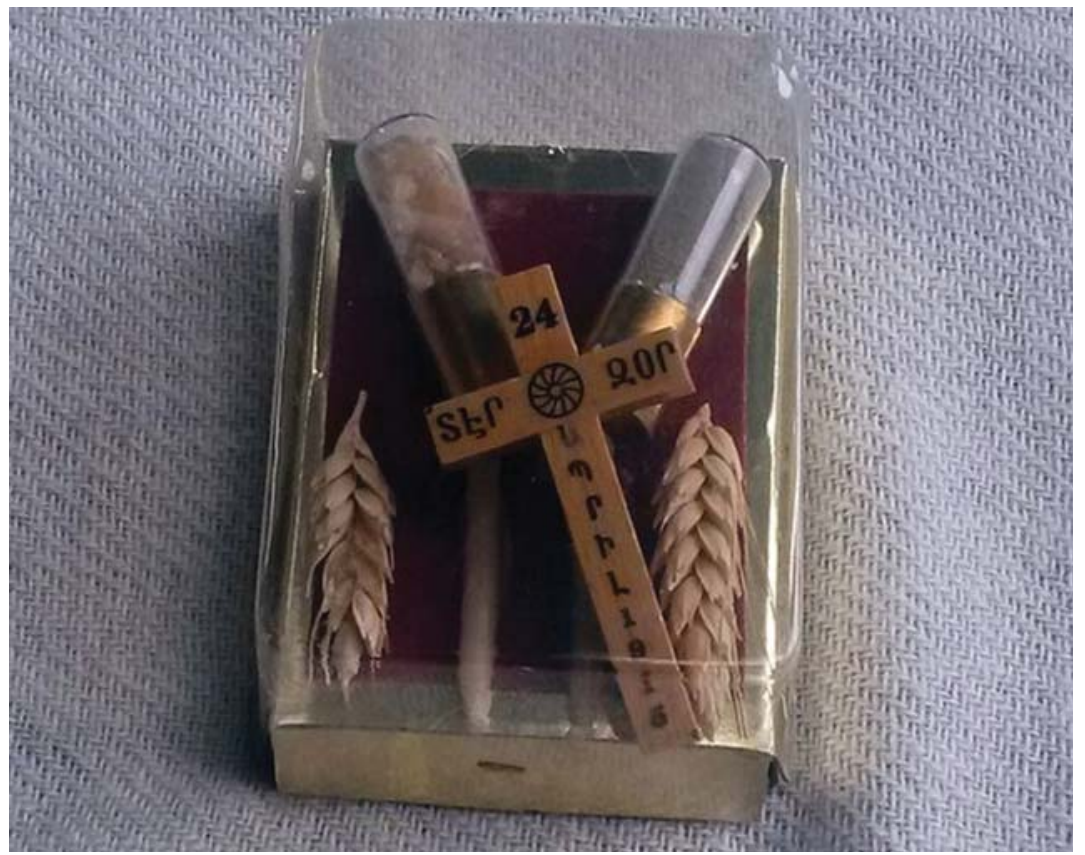

Figure 6 Photograph of a souvenir box purchased at the Dayr al-Zur Armenian Genocide Memorial. Published with permission from Nourtiza Matossian.

of Christ during communion and consumed by parishioners. The breaking of the bread metonymically seems to replicate not only the breaking of Christ's body on the cross but the symbolic breaking of the bodies of Armenian victims into pieces on the plains around Dayr al-Zur. Matossian remarked that she used the box in Cyprus to inter the bones in a space that she was familiar with, a space she thought of as safe: 'I thought it was important to lay the bones to rest with that little box.' It occurred to me after interviewing her that she had interred the bones on yet another difficult border, since Northern Cyprus was occupied by Turkey in 1974. The bones were taken from one contested border and interred on another.

There is something deeply unsettling about collecting human remains; the practice awakens so many ethical questions within us. Understandably, respondents sometimes grew uncomfortable when I asked them if they collected bones in Dayr al-Zur. Armenian respondents admitted to taking some bones, but often provided different reasons for taking them. A recurring sentiment was that the bones were proof of a crime, evidence that needed to be preserved. Matossian sought to symbolically consecrate and inter the bones in a space that was home to her; she did not feel it was ethical or moral to hold on to them. When asked if he too collected bones, David Barsamian replied: 'I've got them at home. I didn't want to make a tamasha [Hindu: commotion] out of it. [They're] very small bones.' Here, he used the term 
tamasha to indicate his desire not to make a spectacle out of his own bone collecting. In an interview with Peter Balakian, I asked him if he still had his bones from Dayr al-Zur and he responded: 'They are upstairs in my studio, in a glass container so I can see them. It's a bit the way they were displayed in the Dayr al-Zur church. They have spiritual meaning for me and they connect me to the many members of my family who were killed in $1915 .^{\text {,41 }}$

Balakian's response affirms that his collecting and displaying of bones has spiritual meaning for him. Through this spiritual linkage, the bones of Armenian Genocide victims become part of an ancient tradition of collecting fragments of dead saints, saints whose body fragments are displayed for a higher, more noble purpose. Just like the ossuaries in Dayr al-Zur and Margada, yet another ossuary commemorating the Armenian Genocide exists at the site of the Armenian Catholicos in Antelias, Lebanon. The displaying of bones appears to be ethically permissible to the highest spiritual authorities if the body is testifying to something of great import - the memory of a miracle or, in this case, the memory a great crime.

However, such open displays of bones are not universally adopted by Armenians. The ethical dilemma concerning the collection and display of Armenian bones is cleverly addressed by photographer and journalist Diana Markosian in a powerful photo published in Smithsonian Magazine. ${ }^{42}$ In the course of her research, Markosian found an Armenian man in Providence, Rhode Island who had been collecting bones from Dayr al-Zur for some time and had about thirty bone fragments in his possession. The man shipped the bones in the mail to Markosian for her to photograph, but her artistic choice resisted the dominant mode of bone display. She chose to photograph the box unopened in her photo essay (Figure 7). When I asked her about her choice not to display the bones in her photograph, she explained, 'The box felt sacred to me. I didn't want to open it. I also didn't feel like I had the authority to open it - so I photographed it as an artefact rather than an object. ${ }^{33}$

Markosian's photograph of a cardboard box works as critical commentary on the display of Armenian bones found in historic essays, poems and photographs. She reminds us of the sacred power of bones that serves to bookend our discussion. Bones serve a mnemonic function in MacKendrick's textbook metaphor, whereby memory is both conjured and placed within a specific historical narrative. This is where the Armenians come into play, for the relics are not those of saints in the classical sense, whose dismembered parts are permitted to be collected and displayed in the context of devotion. In the case of Armenian pilgrims, ancestors are dug up and collected to serve another sacred purpose as bone memory. The bones simultaneously serve as a metonym for a lost community scattered in the Syrian desert. Therefore, it is not only through pilgrimage and ritual performances that Armenian identity is enacted in the affective space of Dayr al-Zur. Material bones together with humans enact the memory of a lost community. MacKendrick writes, 'Fragmentation evokes wholeness,' because bones in fragments are able, through their anonymity, to conjure the collective memory of community. ${ }^{44}$

The Armenian pilgrimage practices reconstructed in this article were conducted before the Syrian War and the subsequent destruction of the Armenian Genocide Memorial in Dayr al-Zur by ISIS in September 2014. Armenian pilgrimage 


\section{Elyse Semerdjian}

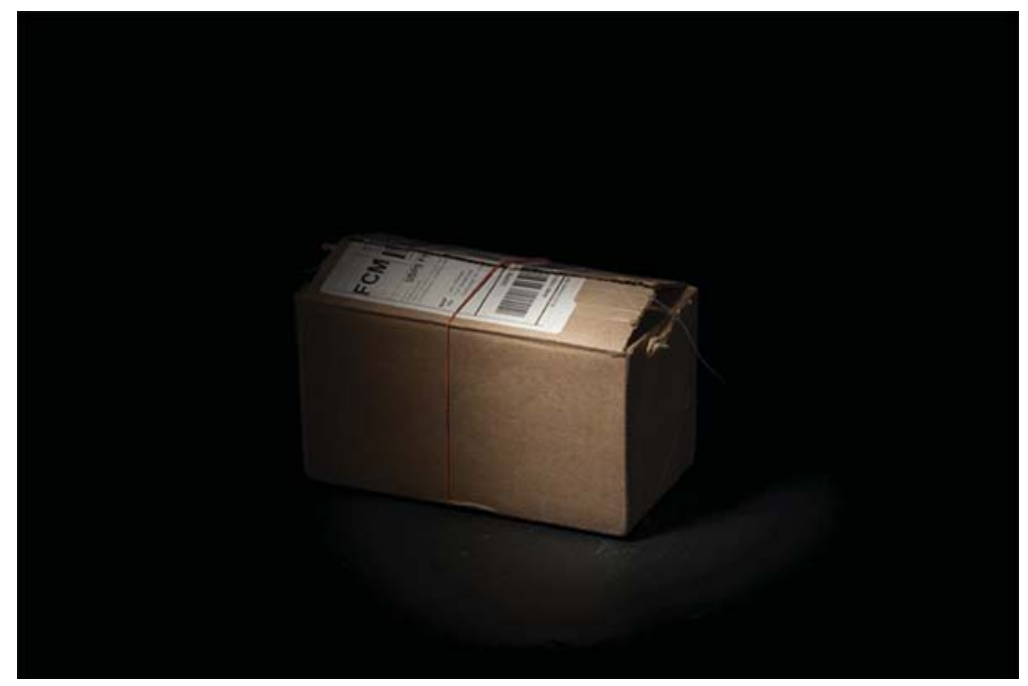

Figure 7 Original caption: 'Hundreds of thousands of Armenians were marched into the Syrian desert. Above a box contains the bones of an Armenian who died there.' Published with permission from Diana Markosian. All rights reserved; permission to use the figure must be obtained from the copyright holder.

rituals offer us a way to think about the history that lies beneath the affective landscape of Dayr al-Zur. Yet, the bones of Armenians scattered in the Syrian desert are hardly a display. The abandonment of bones in the landscape can inspire us to think of the ethical implications of the largely unmarked space where hundreds of thousands perished. Thinking about century-old Armenian bones in the desert should not detract from reports of mass graves of ISIS victims recently discovered in Dayr al-Zur. ${ }^{45}$ If so few remember the Armenians today, even fewer will remember Sunni Muslim victims in Dayr al-Zur - Arab tribesmen who resisted the repugnant black flag. Ironically, many Arabs of the desert are the descendants of intermarriage between local Arabs and Armenian women genocide survivors who were marched into the desert.

What should be remembered at Dayr al-Zur at the war's end? I posed this question to Peter Balakian, who replied, 'It would be important for the Armenian monuments to be remade. This is a historical ground with large ethical significance for the world - not just for Armenians. A small part of Dayr al-Zur could become a kind of Peace Park - if there were the right kind of leadership involved, and a place where human rights atrocities are reckoned with. Historical memory in public spheres matters to all nations, and as the largest grave yard of the Armenian Genocide, Dayr al-Zur is a tragic and morally important place and space. ${ }^{46}$ Within the intertwined histories embedded in the desert surface, Christian and Muslim bones are now comingled, prompting one to imagine, as Balakian suggests, a shared memorial on the site at war's end. 


\section{Acknowledgements}

I would like to thank Khatchig Mouradian for offering me an interview and for leading me to other pilgrims who continue to be haunted by Dayr al-Zur. My gratitude goes to the pilgrims who trusted me with their experiences in the Syrian desert and to Diana Markosian, who generously offered her photograph for reprinting. Last but not least, many thanks for Gemma Angel for encouraging me to document pilgrimage practices that remain largely obscure to Armenians outside the Levant.

\section{Notes}

1 The original essay was published in Armenian as Hamasdegh, 'Qangi me hed' (With a Skull). I have chosen to retain the original title 'With a Skull'. The essay was later translated into English as Hamasdegh, 'Journey with a Skull' for Armenian Weekly Magazine, 11 May 2010, https://armenianweekly.com/2010/05/11/ hamasdegh-journey-with-a-skull/, accessed 13 February 2018. I would like to thank Khatchig Mouradian for drawing my attention to the essay.

2 I have found the new materialist arguments insightful as I consider more fully human interactions with bones in Dayr al-Zur. See J. Bennett, Vibrant Matter: A Political Ecology of Things (Durham, NC, Duke University Press, 2014) and E. Hallam, 'Articulating Bones: An Epilogue', Journal of Material Culture 15:4 (2010), 465-92.

3 J. Fontein, 'Between Tortured Bodies and Resurfacing Bones: The Politics of the Dead in Zimbabwe', Journal of Material Culture, 15 (2010), 430.

4 G. Balakian, Armenian Golgotha: A Memoir of the Armenian Genocide 1915-1918, trans. P. Balakian with Aris Sevag (New York, Vintage, 2009) p. 250. I have included a question mark to the quotation that is missing in the original.

5 While the term 'pilgrimage' has been used in many contemporary accounts, some respondents rejected the term, describing their journeys in political terms.

6 It has become common for Armenians to share their experiences in digital formats produced by Armenian publishers.

7 German photographer Armin Wegner, a German medic turned human rights activist stationed in the Ottoman empire, is perhaps the most prominent photographer of Turkish atrocities against the Armenians. Noteworthy are his photographs of hundreds of Armenian deportees in Dayr al-Zur. Eyewitnesses and survivors commented on the importance of photography in providing objective, scientific evidence of the Armenian massacres. See Stanley E. Kerr's discussion of the use of the camera to document war orphans in The Lions of Marash: Personal Experiences with American Near East Relief (Albany, NY, State University of New York Press, 1973), p. 76. See Huberta von Voss's interview with Nouritza Matossian in which she remarks 'photos have become the Armenians' main evidence in their toilsome task to obtain international recognition', in Portraits of Hope: Armenians in the Contemporary World (New York, Berghahn Books, 2007), p. 97.

8 Achille Mbembe, building on the thought of Michel Foucault, argues that sovereignty is expressed as the right to kill, and this includes, by extension defining 


\section{Elyse Semerdjian}

whose lives are disposable and, by that logic, denied memory. See A. Mbembe, 'Necropolitics', trans. Libby Meintjes, Public Culture, 15:1 (2003), 16.

9 'Battle Over History', CBS (Columbia Broadcasting System), 60 Minutes, 26 February 2010.

10 P. Balakian, 'Bones', New York Times Magazine, 5 December 2008.

11 Peter Balakian's writing on the Armenian Genocide is quite extensive. Besides the previously mentioned translation of Grigoris Balakian's memoir, some prominent examples of his writing and commentary include Black Dog of Fate: A Memoir (New York, Basic Books, 1997), Burning the Tigris: The Armenian Genocide and America's Response (New York, Harper Collins, 2003), 'The Armenian Genocide', dir. Andrew Goldberg (2006), and 'Battle Over History', 60 Minutes (2010).

12 'Battle over History'.

13 G. Balakian, Armenian Golgotha, p. 241. I will refer to him as Grigoris vardapet (celibate priest) to distinguish him from his great-nephew, who shares the same patronym.

14 D. Chatty, Displacement and Dispossession in the Modern Middle East (New York, Cambridge University Press, 2010), pp. 161-3.

15 F. Lawson, 'The Beginning of a Beautiful Friendship: Syrian-Turkish Relations since 1998, in F. Lawson (ed.), Demystifying Syria, (London, Saqi Books, 2012), p. 111.

16 I am refraining from listing the titles of banned books, in order to protect the authors. Needless to say, mentioning this phenomenon and a banned book on a scholarly listserve a decade ago immediately caused the Syrian secret police to visit the home of the author.

17 The notion of -scapes through which to think of global assemblages was introduced in the second chapter of Arjun Appadurai's 'Disjuncture and Difference in the Global Cultural Economy', Public Culture, 2:2 (Spring 1990), 1-11, 15-24; the genealogy and meaning of the concept of 'deathscape' can be found in A. Maddrell and J. D. Sidaway (eds), Deathscapes: Spaces of Death, Dying, Mourning, and Remembrance (London, Routledge, 2010), pp. 4-5.

18 Both quotes in this and the previous paragraph are from Balakian, Armenian Golgotha, p. 250.

19 Methods used to sanitise the health threat posed by decomposing Armenian bodies are discussed in R. Kévorkian, 'Earth, Fire, Water: or How to Make the Armenian Corpses Disappear', in É. Anstett and J.-M. Dreyfus (eds), Destruction and Human Remains: Disposal Concealment in Genocide and Mass Violence (Manchester, Manchester University Press, 2014), pp. 94-5.

20 Balakian, Armenian Golgotha, p. 242.

21 N. Migliorino (Re)constructing Armenia in Lebanon and Syria: Ethno-Cultural Diversity in the Aftermath of a Refugee Crisis (New York, Berghahn Books, 2008), p. 195.

22 Kévorkian, 'Earth, Fire, Water', 89-117.

23 The Armenian National Institute (ANI) created an online catalogue of all Armenian Genocide Memorials, 'Monument and Memorial Complex at Der Zor', 
ANI, www.armenian-genocide.org/Memorial.110/current_category.72/ memorials_detail.html, accessed 13 February 2018.

24 Interview with Rania Masri, 27 March 2017. Although Masri travelled to Dayr al-Zur with Armenians, she is not Armenian, yet her words aid our understanding of the affective quality of the memorial before its destruction.

25 K. MacKendrick, Fragmentation and Memory: Meditations on Christian Doctrine (New York, Fordham University Press, 2008), p. 123.

26 See 'Memorial at the Armenian Apostolic Church in Margadeh, Syria', ANI, www.armenian-genocide.org/Memorial.111/current_category.72/memorials_ detail.html\#memorial_image, and Kévorkian, 'Earth, Fire, Water,' 107.

27 Kévorkian, The Armenian Genocide: A Complete History (London: I. B. Tauris, 2011), p. 664.

28 Kévorkian, 'Earth, Fire, Water', 106.

29 Interview with Sa'ad Hamad al-As'ad, Shaddadi, Syria, 23 November 2007.

30 Here I borrow a phrase from Robert M. Bednar's study of the removal of roadside car crash memorials. See R. M. Bednar, 'Killing Memory: Roadside Memorial Removals and the Necropolitics of Affect', Cultural Politics, 9:3 (2013), 339.

31 Interview with David Barsamian, 4 April 2017.

32 'Battle Over History'.

33 This concept is influenced by the thinking of sociologist Asef Bayat, whose concept of 'everyday resistance' and 'quiet encroachment' allows us to register small acts as larger social and political movements: A. Bayat, Life as Politics: How Ordinary People Change the Middle East, 2nd edition (Stanford, CA, Stanford University Press, 2013).

34 Balakian, 'Bones'.

35 Interview with Khatchig Mouradian, 24 March 2017.

36 Interview with Rania Masri, 27 March 2017.

37 MacKendrick, Fragmentation and Memory, p. 117.

38 J.-L. Nancy, Birth to Presence (Stanford, CA, Stanford University Press, 1993), p. 143 quoted in MacKendrick, Fragmentation and Memory, p. 119.

39 Nouritza Matossian is an accomplished actress and writer, author of Black Angel: The Life of Arshille Gorky (New York: The Overlook Press, 2002).

40 Interview with Nouritza Matossian, 26 March 2017.

41 Interview with Peter Balakian, 26 May 2017.

42 D. Markosian (photographs) and J. Krajeski (text), 'One Photographer's Personal Endeavor to Track Down Survivors of the Armenian Genocide, 100 Years Later', Smithsonian Magazine (July 2015). I would like to thank Khatchig Mouradian for bringing this photograph to my attention.

43 Diana Markosian, email communication, 9 April 2017.

44 MacKendrick, Fragmentation and Memory, pp. 123 and 128.

45 For some news coverage of the killing of 700 Shaytat tribesmen and more see 'Da'ash yu'adam arba'ah min 'ashirat al-shaytat al-suriyya', al-Hayat, 27 October 2014, www.alhayat.com/m/story/5312739, accessed 13 February 2018.

46 Interview with Peter Balakian, 26 May 2017. 